\title{
Globalization, regionalization, and borders
} Mundialização, regionalização e fronteiras

\author{
(1) Maria Izabel Mallmann* \\ (1) Sebastian Santander** \\ Gustavo Matiuzzi de Souza**
}

$\mathrm{T}$ he profound changes in the international system in recent decades, such as the development of regional dynamics, the expansion of commercial, financial and institutional flows in the global spheres, as well as the State's responses in the attempt to maintain control of these dynamics revealed important sociopolitical tensions in the interactions of agents in local, regional and global scales and levels (Stefanova, 2018). The expansionist dynamics of mondialisation, which have long been generated from Europe, have been accelerated and deepened under the effect of globalization. The profusion of agents and themes with international incidence has also grown exponentially, articulating economic, cultural, social, political and ecological logics beyond national borders, which mitigates the regulatory capacity of States and their cooperative arrangements and subtracts the operational efficiency of regional and international institutions (Söderbaum, 2016).

The transformations and mutual determinations of global, regional and local realities make indispensable to bring to light the articulations between the various levels that make up the international system. Such interrelationships can point out systemic and domestic causes of regionalism, their limits and challenges, as well as their potential and multiple manifestations, revealing, once analyzed, the institutional properties of States and organizations as well as other actors that relate to each other (Telò, 2007). The various types of

\footnotetext{
* Independent researcher in Porto Alegre, RS, Brazil.

** Université de Liège (Liège, Belgium).

authors.biographic_data
} 
regionalism in the spheres of globalization - more economic, homogenic, and controlled by global powers - and/or 'mondialisation' - more cultural, cosmopolitical, and plural - (Tassin, 2012), as well as their roles and implications, become of ultimate relevance, structuring regionalization processes, (re)construction of borders (and cross-border regions), activities of paradiplomacy, migration flows, and demonstrations of regional and global leadership, inasmuch as different actors, understood as agents in such a system (Wendt, 1999), interact with each other, reinforcing or combating the system, or even engendering new modus operandi and connections.

With an interdisciplinary approach, this dossier contributes to such reflections, gathering national and foreign authors, and discussing theories and cases that can help in understanding this intricate reality. Opening this issue, Regionalism in a globalized multi-polar economy, by Sebastian Santander, discusses the way global changes shape regional organizations and their ability to face challenges and difficulties coming from globalization. In his analysis, the main world players (China, Russia, the United States and the European Union) seek to shape global processes to their preferences, with regionalism being 'an intermediate stage' between the once national scope and the liberal dynamics arising from globalization. In this way, both regionalism and globalization do not appear as antagonistic but as complementary processes. At the same time, the various political projects that base the answers to such challenges end up shaping different pathways and speeds of regionalization, which respond to specific situations and to unique stories and face competition with other regional cooperation and integration initiatives.

In Notions of border in regionalism theory and praxis: a critical overview, Gustavo Matiuzzi de Souza departs from the assumption that regionalisms and borders are mutually related social constructions, as in empirical as in conceptual terms, and as such, little was dealt with in the context of the theories of International Relations and of Regionalism in particular. By relating three empirical phases of regionalism with the development, in parallel, of notions of border in theories on the theme, his study points out important variations in the understanding and application of what would be the border. In this context, the strengthening of regional dynamics, in their most diversified models, appears, according to Matiuzzi, along with the rebuilding of border barriers and nationalistic discourses and policies. Both processes, seemingly contradictory, grow under the aegis of 
a global and globalizing system, which would require the application of a globalist perspective for their better understanding.

The article by José Briceño Ruiz and Philippe De Lombaerde, Regionalismo latino-americano: produção de saber e criação e importação de teoria, revisits the contributions of Latin American thinking about regionalism and discusses the comparability between integration experiences and the effective influence exerted by European integration on regional initiatives in Latin America. The authors maintain that the comparison is valid, since the theories developed in the basis of the European case have sufficiently abstract content to subsidize contrast, which would not mean the presumption of assimilation of the European way by the various cases of integration, be they Latin American or not.

Local dynamics and regionalization processes take varied forms in border regions, in which the rescaling of economic, political and social processes is conspicuous and highlights the tensions between State and other local, regional and global logics (Jessop, 2003). This border complexity stands out in the analysis by José Lindomar Coelho Albuquerque, Identidades em territórios de fronteira: os casos de Ceuta e Gibraltar na fronteira entre a África e a Europa, which addresses specificities of identity construction in these areas. The author argues about the relevance of the analyzed cases of Ceuta and Gibraltar, since they are territories claimed by Morocco and by the United Kingdom and because they constitute 'total border spaces', situated between States, continents and seas, and embracing ethnic and religious divides, as well as the tension between the fear of territorial loss and the zeal for the political and cultural bonds with their respective metropolises.

Contrasting from the case by Albuquerque, Felipe Comunello analyzes, in O ativismo cultural e a imaginação da fronteira Brasil-Uruguai, the actions of agents and political movements in defense of cultural policies, and the way in which they mobilize the idea of border as a common cultural space in this border region of intense local interrelations. Comunello notes a tendency to concurrency between cultural activism and professional affirmation of agents demanding free movement in the region. This inclination allows to discuss the political articulations around the symbolism of the border, enabling to investigate other similar border regions.

In Paradiplomacia y relaciones transfronterizas, Isabel Clemente addresses paradiplomatic experiments in Latin America, the United States, 
and China. It does so to demonstrate the variation of actors and resources applied, the different spatial scales connected, whether in situations of territorial contiguity or of separation by large distances. Clemente inserts the investigation into the discussion on globalization and mondialisation and into the outburst of the local dimension as an important level of analysis. Situated in the constructivist perspective, her analysis identifies, in certain cases, the process of actors formation in their local and regional intersubjective relations, which evoke shared memories and expectations. In other situations, in which the conduct of the paradiplomatic practices by the State is evident, the realistic arguments would be best illustrated. This is the Chinese case, whose specificity consists, according to Clemente, in the use of paradiplomacy as an instrument of the foreign policy of the central government.

La paradiplomacia local y transfronteriza como un instrumento de gobernanza ambiental en América Latina, by Nahuel Oddone, Horacio Rodríguez Vázquez and Martín Quiroga Barrera Oro, exemplifies how much paradiplomacy has contributed to the environmental governance. In the context of different regional experiences in South America and Europe, the text points out that the challenges posed by climate change induce the coordination of efforts by public and private actors from distinct levels of government in order to enable environmental governance, in which local actors can generate efficient responses to global problems. In view of the potential for conflict embedded in such processes, paradiplomacy and local governments should focus on generating consensus to promote stability to negotiations and to environmental development strategies.

Solène Marié relates, in Cultural paradiplomacy institutions and agenda: the case of Rio Grande do Sul, Brazil, the paradiplomatic exercise to the international projection of identity from the case analysis of the Brazilian federated state of Rio Grande do Sul, from 1987 to 2014. Two dimensions are analyzed, the paradiplomatic and cultural institutions of the federated state and the paradiplomatic agenda itself. The oscillating agenda in the period studied, especially with regard to culture, and the projection of the microregional identity, effective in the levels of the federated state and of the nation, are debilitated at the international level, without a long-term, structured project and remaining captive of each new government orientation.

In the last article of the dossier, El liderazgo brasileño en Sudamérica en tiempos de cambio: una mirada desde Uruguay, Camilo López Burián 
and Carlos Luján address the influence and regional projection of Brazil from the analysis of the perceptions of Uruguayan legislators and seek to assess the impact that the Brazilian crisis and the reconfiguration of the world scenario may have on the international action of South American countries. The issue of regional leadership is rekindled, as is the discussion on the need for dispersing integration costs to the countries that engender such mechanisms.

The book review of Bertrand Badie's Un monde de souffrances. Ambivalence de la mondialisation, here entitled The empire of pain, by Daniel Afonso da Silva, places in the foreground the problematic of human suffering arising from the irreversible inclusion of people on the international scene as one of the effects of globalization.

What all investigations touch is the question of the increase of complexity of the global reality vis-à-vis the ever-changing nature of the international system, which, despite the rise of issues, actors and institutions in play, continues to be driven, in a somewhat more limited degree, by States (their territorial and jurisdictional logics included, and hence, of border), their political and economic agendas, and the interests of groups circumscribed within both national and regional spheres. The repercussions of such intricate interrelations are depicted, in each article, according to a diverse set of understandings on globalization and on the international system, as well as of their respective functioning processes, which will certainly contribute to the reader's deeper comprehension of these phenomena.

In the Articles section, we present three papers developing anthropological perspectives on children's participation in productive activities. In his article, Medaets discusses this theme, based on his observations in riverine communities in the region of the Tapajós River, in the state of Pará, Brazil. In this area, children contribute to, and are even a fundamental link in, the development of the work of cassava farming as well as of the tuber's flour production. Mobilizing the literature on childhood and family agriculture in Brazil, the author shows that the children's 'help' is practically the rule in various areas. In the Tapajós, as in other places, the characteristics of the activities developed by children are not incompatible with school attendance and play. Thus, the question on the framing of these activities as 'child labor', in the sense given to this expression by multilateral organizations, such as Unicef and the International Labor Organization (ILO), becomes pertinent. Medaets insists on the learning involved in the 'help' of children, showing 
that, for their interlocutors, the two things (learning and helping) go together, and that those who do not go through this process (do not 'help') end up not mastering indispensable knowledge and will find it difficult to continue managing their parents' farms.

Mézié describes the work experience of 7-to-12-year-old boys who exploit a small stone quarry in a rural area of Southwestern Haiti and use the money they earn to buy animals (chickens, a goat). They then expect the animals to grow and raise their offspring for selling, so that they can raise enough money for, one day, when they are about 18 years old, buy a piece of land. What draws attention to the situation described by the author is that children seek this work on their own initiative. Comparing with research done in other regions of Haiti and in other periods, Mézié shows that throughout the country it is common for parents to encourage their children to cumulatively purchase animals. Children of families with more opportunities may even receive their first chicken as a gift. The boys observed by Mézié come, nevertheless, from families among the poorest of their areas. As observed in the article of Medaets on children of the Tapajós, the Haitian children also mix work, attendance to school, and fun. For them, the playful aspect takes on a musical form. They sing and play in the various intervals they perform during work, as seen in the short film by the author and accessible through the link indicated at the end of the article.

Finally, taking from the Argentine context, Zuker's article critically reviews the studies focused on the relationship between child labor and health, emphasizing its characteristics and scope. The author is interested in seeing whether these studies explore alternative approaches to the subject beyond the framework of ILO laws and recommendations. These documents, through conviction and labor regulation, tend to treat equally practices that are quite diverse in terms of potential damage to child development. In the perspective developed by the author, moral condemnation and illegality of child labor are expressed in the absence of systematic research and updated statistics that can contribute to approaches of the theme in its intricacy.

\section{References}

JESSOP, Bob. The political economy of scale and the construction of crossborder micro-regions. In: Fredrik Söderbaum; Timothy M. Shaw (eds.). Theories of new regionalism: a palgrave reader. Basingstoke: Palgrave Macmillan, 2003. p. 179-196. 
SÖDERBAUM, Fredrik. Rethinking regionalism. London: Palgrave Macmillan, 2016.

STEFANOVA, Boyka M. The European Union and Europe's new regionalism: the challenge of enlargement, neighborhood, and globalization. London: Palgrave Macmillan, $2018<10.1007 / 978-3-319-60107-6>$.

TASSIN, Étienne. La mondialisation contre la globalisation: un point de vue cosmopolitique. Sociologie et sociétés, v. 44, n. 1, p. 143-166, $2012<10.7202$ / 1012146ar>.

TELÒ, Mario. European Union and new regionalism: regional actors and global governance in a post-hegemonic era. 2nd ed. Aldershot: Ashgate, 2007.

WENDT, Alexander. Social theory of international politics. Cambridge: University Press, 1999.

MARIA IZABEL MALLMANN <izabel.mallmann@gmail.com>

$\mathrm{PhD}$ in Political Science at the Sorbonne Nouvelle (Paris III, Paris, France) with post-doctorate degree at the Instituto de Relações Internacionais da Universidade de Brasília (UnB) in Brasília, DF, Brazil. Is independent researcher in Porto Alegre, RS, Brazil.

ORCID: http://orcid.org/0000-0003-1423-0571

SEBASTIAN SANTANDER <sebastian.santander@uliege.be>

$\mathrm{PhD}$ in Polítical Science at the Université Libre de Bruxelles (Brussels, Belgium), full professor at the Faculté de Droit, Science Politique et de Criminologie of the Université de Liège (Liège, Belgium).

ORCID: https://orcid.org/0000-0002-4172-6778

GuSTAVO MATIUZZI DE SoUZA < gustavo.matiuzzi@gmail.com>

$\mathrm{PhD}$ in Social Sciences by the Pontificia Universidade Católica do Rio Grande do Sul (Pucrs, Porto Alegre, RS, Brazil) and the Université de Liège (ULG, Liège, Belgium), member of the Núcleo de Estudos sobre Relações e Organizações Internacionais at Pucrs in Porto Alegre, Brazil and lecturer in the Center for International Relations Studies (Cefir) of the ULG in Liège, Bélgica.

ORCID: http://orcid.org/0000-0003-3523-626X 